\title{
The Impact of the Policy of Karawang City Government in Tourism Development to Support Family Economics in Segaran Village
}

\section{Hamiyati Hamiyati and Shinta Doriza}

Pendidikan Kesejahteraan Keluarga Studies Program, University Negeri Jakarta, Indonesia

\section{Abstract}

The discovery of the Batujaya Site has made many people interested in visiting Segaran Village as tourists. The village that was completely unknown is now visited by many tourists, especially during Waisak celebrations every year. An increase in the number of tourists certainly brings blessings to the family of Segaran Village. On the other hand, the lack of policies in regulating tourists made Segaran Village only able to observe income from tourists once a year. The research aims to explore tourism policy as an impact of the increasing number of tourists in Segaran Village. The research

Corresponding Author: Shinta Doriza shintadoriza@unj.ac.id

Received: 11 January 2019 Accepted: 14 February 2019 Published: 25 March 2019

Publishing services provided by Knowledge E

(c) Hamiyati Hamiyati and Shinta Doriza. This article is distributed under the terms of the Commons Attribution License, which permits unrestricted use and redistribution provided that the original author and source are credited.

Selection and Peer-review under the responsibility of the 3rd ICTVET 2018 Conference Committee.

\section{G OPEN ACCESS}

\section{Introduction}

The site of the fourth- and fifth-century Tarumanegara kingdom was found in Karawang in 1984. This site is known as the Batujaya Site. The Batujaya site contains temples. Like the Soul Temple, Resin 1 and 2, Blandongan, and Temple Lempeng. The temples are characterized as Buddhist temples because they are made of red bricks. Why is that? Because this site is located in the middle of a stretch of rice fields belonging to the community in Batujaya District, precisely Segaran Village, Karawang Regency.

The discovery of the site made Karawang more known. The existence of the site has made many people interested in visiting Segaran Village as tourists. The village that was not known to be a village that is visited by many tourists, especially during the celebration of Waisak.

The number of tourists visiting is increasing every year. This is in accordance with the research An increase in the number of tourists visiting an area will have an impact on increasing tourist expenditure directly as an injection of funds for the economic development of the region [1], especially Desa Segaran. 
The results of the preliminary research through interviews with the Head of Segaran Village, it turned out that the visit of tourists brought blessings to the family of Segaran Village, especially during Vesak day [2]. These results were also supported by interviews with residents of Desa Segaran, they said that their income had increased during the celebration of Vesak day. They earn their income by selling, such as food, drinks, etc. [3]. However, the increasing number of tourists who come makes the village traffic conditions fall apart. Like, inadequate parking lots, tourist vehicles are parked carelessly. This has an impact on congestion on the Segaran Village highway.

Based on the background above, it is necessary to ask how is tourism policy in Segaran Village? While policies on tourism issues are under the responsibility of district institutions, especially Karawang Regency. This study aims to describe tourism policy as an impact of the increasing number of tourists in Segaran Village. Like, what has been done by the Karawang Regency Government so far, how the impact of the policies that have been carried out, and subsequent policies. That is, how the Desa Segaran family in particular and the Karawang regency government can enjoy additional income not only on Waisak days.

\section{Methods and Equipment}

\subsection{Methods}

The method used in this research is descriptive qualitative research method. Data collection was carried out using an open questionnaire and a closed questionnaire with resource persons from the Head of the Karawang District Tourism Office, Head of Segaran Village, Temple Officers, and Families as residents of Segaran Village. Data collection is done through interviews and observations. The research data analysis technique uses an interactive analysis model.

\section{Results}

Tourism development in Segaran Village, which is under the Karawang Regency Tourism Service, has a principle that is integrated with tourism development in West Java Province. This principle guarantees the sustainability of supporting resources for tourism development that are integrated with the natural, cultural and human environment. This means that the development of Segaran Village tourism has been contained in Regional Regulation No. 15 of 2015 concerning the Master Plan for the 
Development of West Java Province Tourism for 2016-2025, namely: Karawang-Bekasi Tourism Destinations and the surrounding area with the DPP center is Bekasi Regency.

Formulating the direction of development policy World-leading tourist destinations can lift tourism destinations in West Java so that they are world-famous. In line with this policy, a document on the world's major tourism plans was prepared in West Java which at least included, among others: 1) The main issues and problems of worldclass tourist destinations; 2) Advantages of tourist destination areas; 3) The future of tourist destinations by the end of 2025; 4) Concept of problem-solving approaches; 5) Defining and conceptualizing the direction of world-class tourism development and development management; 6) Concept of Key Performance Indicators as a standard for the success of world-class tourism development and development management; 7) Tourism businesses that can be developed for the community in tourist destination areas; and 8) The concept of marketing world- class tourist destinations.

Based on the results of a study of West Java's tourism policy and its related, tourism territorial forms that divide administrative areas into Tourism Development Areas (WPW), Tourism Area Units (SKW), with Objects and Tourism Attractions (ODTW) clusters felt less effective because it does not or does not provide clear direction for implementing tourism planning at the provincial level. Therefore, this West Java Province Worldclass Tourism Destination Development adheres to a tiered and superior development concept. The spatial aspects of tourism planning are discussed in the context of a leading tourist area. This is in accordance with Law No. 9 of 1990 concerning Tourism, Chapter I General Provisions, that Tourism Areas, namely areas with a certain area built or provided to meet tourism needs. This definition refers more to tourism areas in the form of resorts, whose regional businesses are managed by limited liability companies or cooperatives. While the tourist area on West Java RIPPDA views the development of tourism as a part or tool in regional development [4]. Like, road networks, flight routes, or cruise ships. Each tourist area has a tourist attraction that must be supported by tourist facilities and services, as well as regional entrance gates that can be in the form of airports, terminals, stations or even highways.

The West Java Province residential tourism area in 2010 has divided the West Java region into eight mainstay areas which in some of the mainstay areas are tourism leading sectors. The division of West Java's tourism area itself has been contained in the West Java Provincial RIPDA in 1996 which is no longer relevant to current conditions. Another document that divides West Java into tourism planning areas is the Tourism Development Planning Book in West Java in 2003. Based on these considerations, West Java Province has tourist area groups with a variety of tourism products offered at 
different development scales -different. For the purposes of planning, it is necessary to determine the tourist areas that have the advantage of attractiveness and can be used as a superior tourist area of the province, or which will be favored by districts/cities in West Java, as a superior tourist district/city.

The development of tourism in West Java is related to the existence and development of road lines in the West Java region which can be broadly divided into three main lines, namely the northern route, the middle lane, and the southern lane. The existence and condition of road access accessibility are one of the important factors that influence the development of tourism in West Java at this time. The movement of tourists from market sources to the tourist attraction of West Java is influenced by the accessibility of the road lines. Puncak tourism area, for example, is closely related to the development of accessibility in the middle lane between Jakarta and Bandung, as a tourist market source, with Bogor and Cianjur

\section{Discussion}

Tourism development must be further developed as sustainable development. Why is that? Because tourism development is one of the development sectors of the country's foreign exchange earners. That is, an increase in foreign exchange certainly is inseparable from the economic perspective that tourism growth is an economic symptom, almost all of which occur in all regions [5]. Tourism development is a development activity that always uses natural resources by taking into account its carrying capacity so that the needs and interests of future generations are not disrupted. In other words, the growth of tourism in various regions must be seen as intervening "invisible hand" which regulates demand and marketing mechanisms in the market [5]. This means that tourism development programs can be carried out through policies that begin with policy analysis so that it can be utilized at the political level in order to solve tourism policy problems [4]. The tourism area development program is carried out by utilizing vacant land for the construction of facilities and infrastructure as well as accommodation in the tourism area and contained in the Republic of Indonesia Law No. 26 of 2007 concerning the arrangement of space article 49 point (b) that the area which when used for tourism activities in space can provide benefits, one of which is to increase community income, especially family income.

The existence of the Vesak celebration turned out to have an impact on the income of the community, in this case, the family in Segaran Village and generally Karawang Regency. This means that the development of tourism in the village must be developed 
because it is in accordance with the principles of tourism development in improving and improving the quality of life of the community and the sustainability of the economy which must guarantee the opportunity for all parties to engage in economic activities through healthy competition [6]. Improving the quality of life of the community generally will certainly improve the family economy. That is, increasing the amount of family income will have an impact on the ability of the family to meet their unlimited needs and desires in order to achieve family welfare [7] in Segaran Village.

\section{Conclusion}

Basically, the programs provided/task of assistance to be carried out by the Village either from the Government, Provincial Government, District and District Governments and Village work programs themselves as village autonomy rights and authority (village origin rights), in principle can be implemented as directed and the conditions given. Although in reality there are still shortcomings in its operational technicality. Constraints or problems and constraints that occur generally can be resolved immediately at the village level by cooperating and coordinating well between village institutions and parties related to others who are competent in their respective fields through deliberations to reach consensus.

\section{Funding}

The research received fund from the Research and Community Service Institutions through the Faculty of Engineering, Universitas Negeri Jakarta.

\section{Acknowledgement}

The authors would like to thank their colleague for their contribution and support for research. Such as: (1) the Ministry of Research and Higher Education of the Republic of Indonesia; (2) the Rector of Universitas Negeri Jakarta; (3) the Institute for Research and Community Service of Universitas Negeri Jakarta; (4) the Faculty of Engineering, Universitas Negeri Jakarta; (5) the Tourism Office of Karawang Regency; (6) and the Head of Segararan Village, Karawang Regency. They are also thankful to all the reviewers who gave their valuable opinions and helped in completing the paper. 


\section{Conflict of Interest}

The authors have no conflict of interest to declare.

\section{References}

[1] Maulida E. Analisis dampak pengeluaran wisatawan terhadap distribusi pendapatan dan perekonomian di Propinsi Bali (pendekatan model Miyazawa). Tesis Fakultas Ekonomi Universitas Indonesia 2003. https://scholar.google.co.id/citations?user= qagh-EkAAAAJ\&hl=en\#d=gs_md_cita-d\&p=\&u=\%2Fcitations\%3Fview_op\% 3Dview_citation\%26hl\%3Den\%26user\%3Dqagh-EkAAAAJ\%26citation_for_view\% 3Dqagh-EkAAAAJ\%3A2osOgNQ5qMEC\%26tzom\%3D-420.

[2] Segaran KD. Wawancara dengan Kepala Desa Segaran. Kabupaten Karawang: 2018.

[3] Desa W. Wawancara dengan warga Desa Batujaya. Kabupaten Karawang: 2018.

[4] Dunn WN. Public policy analysis. Routledge 2015. https://scholar.google.com/ citations?user=LwgqhiQAAAAJ\&hl=id.

[5] Doriza, Shinta dan Muhidin A. ANALISIS PENDEKATAN POLITIK EKONOMI DALAM PENGEMBANGAN WISATA KOTA TUA (Studi Kasus Komunitas Historia Indonesia). EDUKA Jurnal 2016;1:1-35.

[6] Ding, Peiyi; Pigram JJ. The journal of tourism studies. Vol. 6, No. National Centre for Studies in Travel \& Tourism, James Cook University of North Queensland; 1995.

[7] Doriza S. Ekonomi Keluarga. Pertama. Bandung: PT Remaja Rosdakarya; 2015. 